\title{
Temporary Restoration of Bull Trout Passage at Albeni Falls Dam
}

\section{Progress Report}

\author{
Prepared by \\ Brian J. Bellgraph \\ Pacific Northwest National Laboratory \\ Richland, Washington \\ Prepared for \\ U.S. Department of Energy \\ Bonneville Power Administration \\ Division of Fish and Wildlife \\ Portland, Oregon
}

Project No. 2007-246-00

Contract 26934 Release 16

February 2009 


\title{
DISCLAIMER
}

This report was prepared as an account of work sponsored by an agency of the United States Government. Neither the United States Government nor any agency thereof, nor Battelle Memorial Institute, nor any of their employees, makes any warranty, express or implied, or assumes any legal liability or responsibility for the accuracy, completeness, or usefulness of any information, apparatus, product, or process disclosed, or represents that its use would not infringe privately owned rights. Reference herein to any specific commercial product, process, or service by trade name, trademark, manufacturer, or otherwise does not necessarily constitute or imply its endorsement, recommendation, or favoring by the United States Government or any agency thereof, or Battelle Memorial Institute. The views and opinions of authors expressed herein do not necessarily state or reflect those of the United States Government or any agency thereof.

\author{
PACIFIC NORTHWEST NATIONAL LABORATORY \\ operated by \\ BATTELLE \\ for the \\ UNITED STATES DEPARTMENT OF ENERGY \\ under Contract DE-AC05-76RL01830
}

This document was printed on recycled paper.

$(9 / 2003)$ 


\section{Contents}

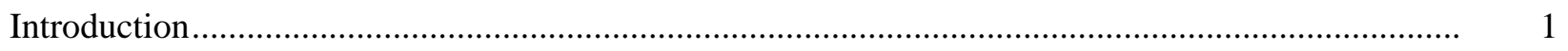

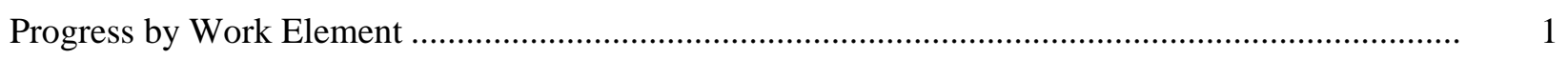

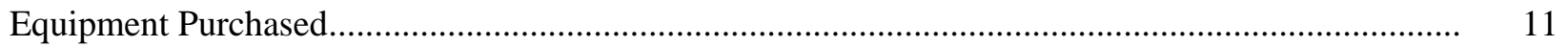

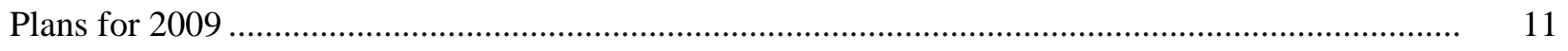

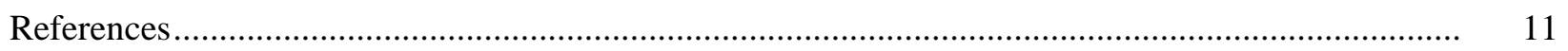




\section{Figures}

Figure 1. Locations of radio receiving monitoring stations on the Pend Oreille River and Pend Oreille Lake tributaries in 2008 4

Figure 2. Locations of radio receiving monitoring stations at Albeni Falls Dam in 2008...............4

Figure 3. Reception range of receivers at Albeni Falls Dam at 1-m depth in spring 2008..............6

Figure 4. Reception range of receivers at Albeni Falls Dam at 5-m depth in spring 2008 ...............7

Figure 5. Reception range of the North Dover and South Dover receivers on the Pend Oreille

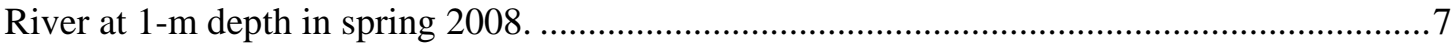

Figure 6. Reception range of the North Dover and South Dover receivers on the Pend Oreille

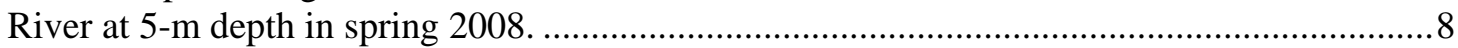

Figure 7. Reception range downstream of Albeni Falls Dam beginning 18 September 2008...........9

\section{Tables}

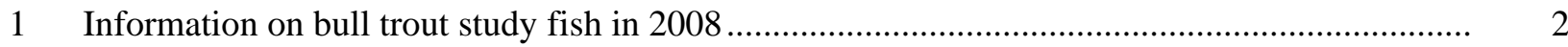

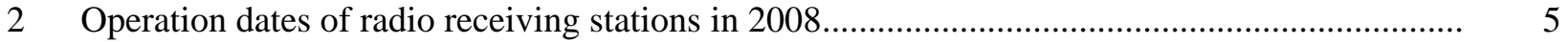




\section{Introduction}

The goal of this project is to provide temporary upstream passage of bull trout around Albeni Falls Dam on the Pend Oreille River, Idaho. Our specific objectives are to capture fish downstream of Albeni Falls Dam, tag them with combination acoustic and radio transmitters, release them upstream of Albeni Falls Dam, and determine if genetic information on tagged fish can be used to accurately establish where fish are located during the spawning season. In 2007, radio receiving stations were installed at several locations throughout the Pend Oreille River watershed to detect movements of adult bull trout; however, no bull trout were tagged during that year. In 2008, four bull trout were captured downstream of Albeni Falls Dam, implanted with transmitters, and released upstream of the dam at Priest River, Idaho. The most-likely natal tributaries of bull trout assigned using genetic analyses were Grouse Creek $(N=2)$; a tributary of the Pack River, Lightning Creek $(N=1)$; and Rattle Creek $(N=1)$, a tributary of Lightning Creek. All four bull trout migrated upstream from the release site in Priest River, Idaho, were detected at monitoring stations near Dover, Idaho, and were presumed to reside in Lake Pend Oreille from spring until fall 2008. The transmitter of one bull trout with a genetic assignment to Grouse Creek was found in Grouse Creek in October 2008; however, the fish was not found. The bull trout assigned to Rattle Creek was detected in the Clark Fork River downstream from Cabinet Gorge Dam (approximately $13 \mathrm{~km}$ from the mouth of Lightning Creek) in September but was not detected entering Lightning Creek. The remaining two bull trout were not detected in 2008 after detection at the Dover receiving stations. This report details the progress by work element in the 2008 statement of work, including data analyses of fish movements, and expands on the information reported in the quarterly Pisces status reports.

\section{Progress by Work Element}

\section{Work Element A: 165 - Produce Environmental Compliance Documentation - Complete environmental compliance requirements}

All procedures involving the handling of bull trout for this study were reviewed and approved by the Institutional Animal Care and Use Committee for Toxicology Northwest and the Pacific Northwest National Laboratory (PNNL) prior to handling fish (IACUC File: 2007-19; Animal Welfare Assurance number: A3353-01). The animal care document is reviewed annually to ensure compliance and to account for changes in the project.

\section{Work Element B: 157 - Collect/Generate/Validate Field and Lab Data - Weekly electrofishing}

Pacific Northwest National Laboratory staff assisted Eastern Washington University (EWU) staff with electrofishing on two trips (one in the spring and one in the fall) in 2008. We will be available to assist EWU with further sampling in spring 2009. 


\section{Work Element C: 28 - Trap and Haul - Transport bull trout above Albeni Falls Dam}

No bull trout were captured during electrofishing trips with which PNNL assisted. Consequently, no fish were transported upstream of Albeni Falls Dam during trips with PNNL biologists.

\section{Work Element D: 158 - Mark/Tag Animals - Implant combination radio acoustic transmitters into bull trout}

No bull trout were captured during electrofishing when PNNL personnel were present. As a result, PNNL staff implanted no fish with combination radio acoustic transmitter (CART) tags. However, four bull trout were captured by EWU and the Kalispel Tribe during other trips, implanted with CART transmitters, and transported to the Pend Oreille River upstream of Albeni Falls Dam (Table 1). Further information on bull trout tagging and genetic analyses can be found in the Kalispel Tribe annual report (Paluch et al. 2009).

Table 1. Information on bull trout study fish in 2008. Genetic origins indicate the most likely and second most likely natal tributaries, respectively. Tag types are CART (combination acoustic and radio tag) and NANO (radio tag only).

\begin{tabular}{ccccccccc}
\hline Code & Tagging Date & Length $(\mathrm{mm})$ & Weight $(\mathrm{g})$ & PIT Tag \# & Collector & Sex & Genetic Origin & Tag Type \\
\hline 126 & 19 May 2008 & 505 & 1178 & 985121002196227 & Kalispel & Unknown & Grouse Creek, Trestle Creek & CART 16_2S \\
128 & 19 May 2008 & 501 & 1133 & 985121002164616 & Kalispel & Female & Grouse Creek, Rattle Creek & CART 16_2S \\
172 & 11 June 2008 & 363 & 374 & 4812405A7F & EWU & Unknown & Lightning Creek, Gold Creek & NANO \\
108 & 18 June 2008 & 496 & 1241 & 985121002194596 & EWU & Female & Rattle Creek, Morris Creek & CART 16_1 \\
\hline
\end{tabular}

\section{Work Element E: 157 - Collect/Generate/Validate Field and Lab Data - Mobile tracking surveys by fixed wing aircraft, vehicle, and boat}

Mobile tracking surveys by aircraft, vehicle, and boat were performed by staff of PNNL and/or EWU in 2008. Specific surveys performed and fish detections by EWU are reported in the Kalispel Tribe annual report (Paluch et al. 2009); fish detections are reported also in Work Element $\mathrm{J}$ as part of the detection history of each fish. Fish detections were recorded using a handheld Global Positioning System (GPS) receiver.

Two boat-tracking surveys were performed by PNNL on Lake Pend Oreille, one in mid-August and one in early October. For the first boat survey, PNNL staff worked with personnel from the Idaho Fish and Game Department who were performing acoustic tracking surveys for tagged lake trout in Lake Pend Oreille. During the second boat survey, acoustic tracking and radio tracking of Pend Oreille Lake occurred simultaneously using a PNNL boat. Points near the mouths of streams identified as potential natal tributaries of bull trout study fish (i.e., Pack River, Trestle Creek, and Clark Fork) were surveyed, as well as points along the shoreline between these tributaries. No bull trout were found during either boattracking survey.

Vehicle mobile tracking by PNNL occurred during the same trips as boat tracking. Mobile tracking by PNNL and EWU was conducted primarily along the Pack River and Grouse Creek complex because 
this tributary did not have a radio receiving station installed to detect fish entering the tributary but was identified as a potential natal tributary of two study fish. Trestle Creek and Lightning Creek also were tracked by vehicle to ensure that fish did not pass the respective radio receiving stations without being detected. Mobile tracking was performed also along the Clark Fork River from Lake Pend Oreille upstream to Cabinet Gorge Dam because one tagged bull trout was located near Cabinet Gorge hatchery by staff of AVISTA (owner of Cabinet Gorge Dam).

\section{Work Element F: 157 - Collect/Generate/Validate Field and Lab Data - Download stationary ground radio receiving stations}

No additional radio receiving stations were installed in 2008. Radio receiving stations installed in 2007 and used in 2008 were

- Albeni Falls Dam spillway tailrace (Tailrace, site 1)

- Albeni Falls Dam spillway forebay (Forebay, site 2)

- Albeni Falls Dam powerhouse tailrace (Logchute, site 3)

- Albeni Falls Dam powerhouse forebay (Cement Pad, site 4)

- mouth of the Priest River (Mudhole, site 5)

- north side of Pend Oreille River near Dover, Idaho (North Dover, site 6)

- south side of Pend Oreille River near Dover, Idaho, and cross-river from site on north side (South Dover, site 7)

- mouth of Gold Creek, a tributary to Lake Pend Oreille (Gold, site 8)

- mouth of Granite Creek, tributary to Lake Pend Oreille (Granite, site 9)

- mouth of Lightning Creek, tributary to the Clark Fork River just upstream of Lake Pend Oreille (Lightning, site 10)

- mouth of Trestle Creek, tributary to Lake Pend Oreille (Trestle, site 11).

These radio receiving locations are shown in Figures 1 and 2. Technical and setup specifications of radio receiving stations can be found in Bellgraph and Deters (2007). The North and South Dover stations each were moved about 100-200 m downstream to private property in 2008 because of vandalism that occurred in 2007. No vandalism of radio receiving stations occurred in 2008. PNNL researchers tested the reception range of each monitoring station after installation of receivers in 2008; details of the testing are explained in Work Element $\mathrm{H}$. 


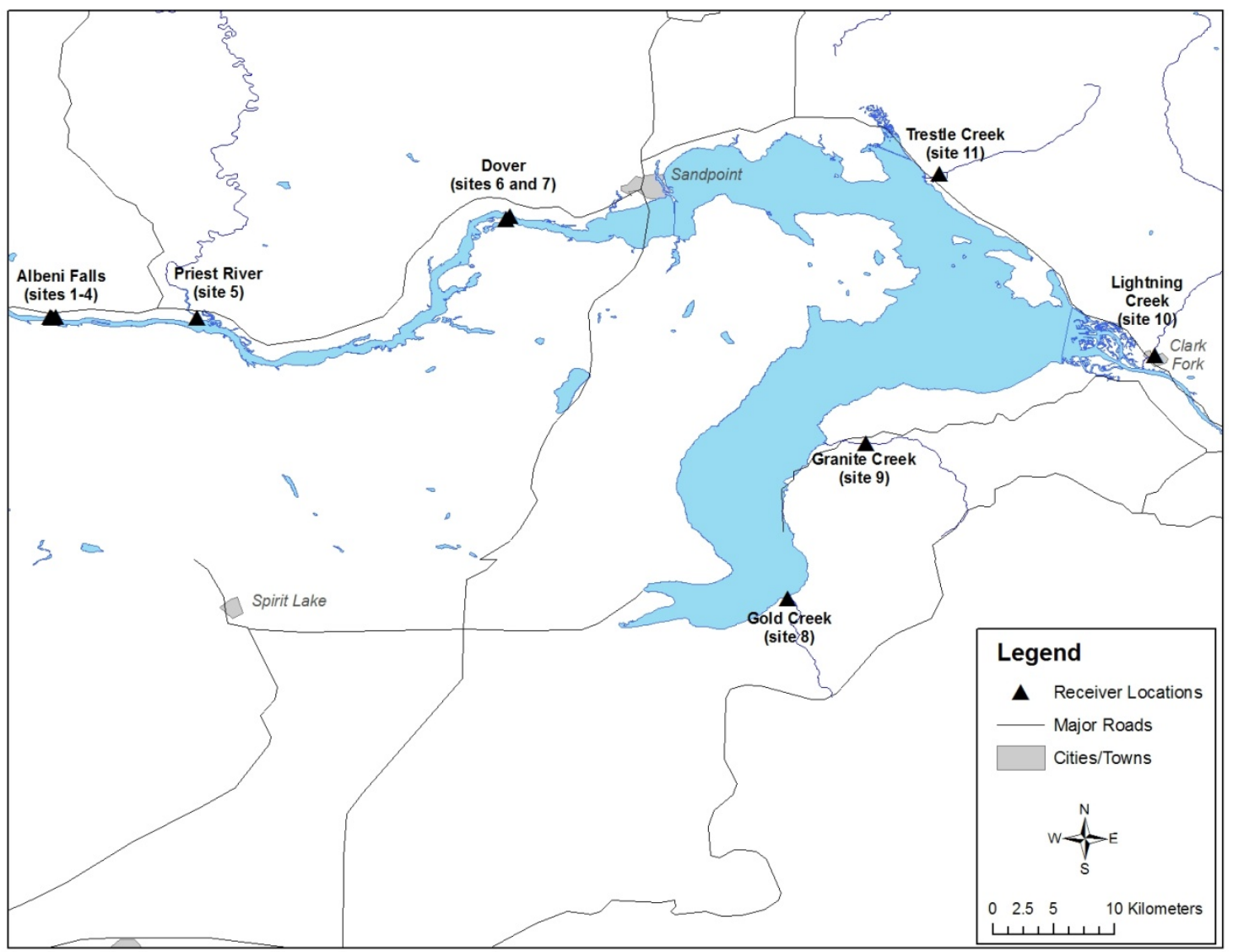

Figure 1. Locations of radio receiving monitoring stations on the Pend Oreille River and Pend Oreille Lake tributaries in 2008

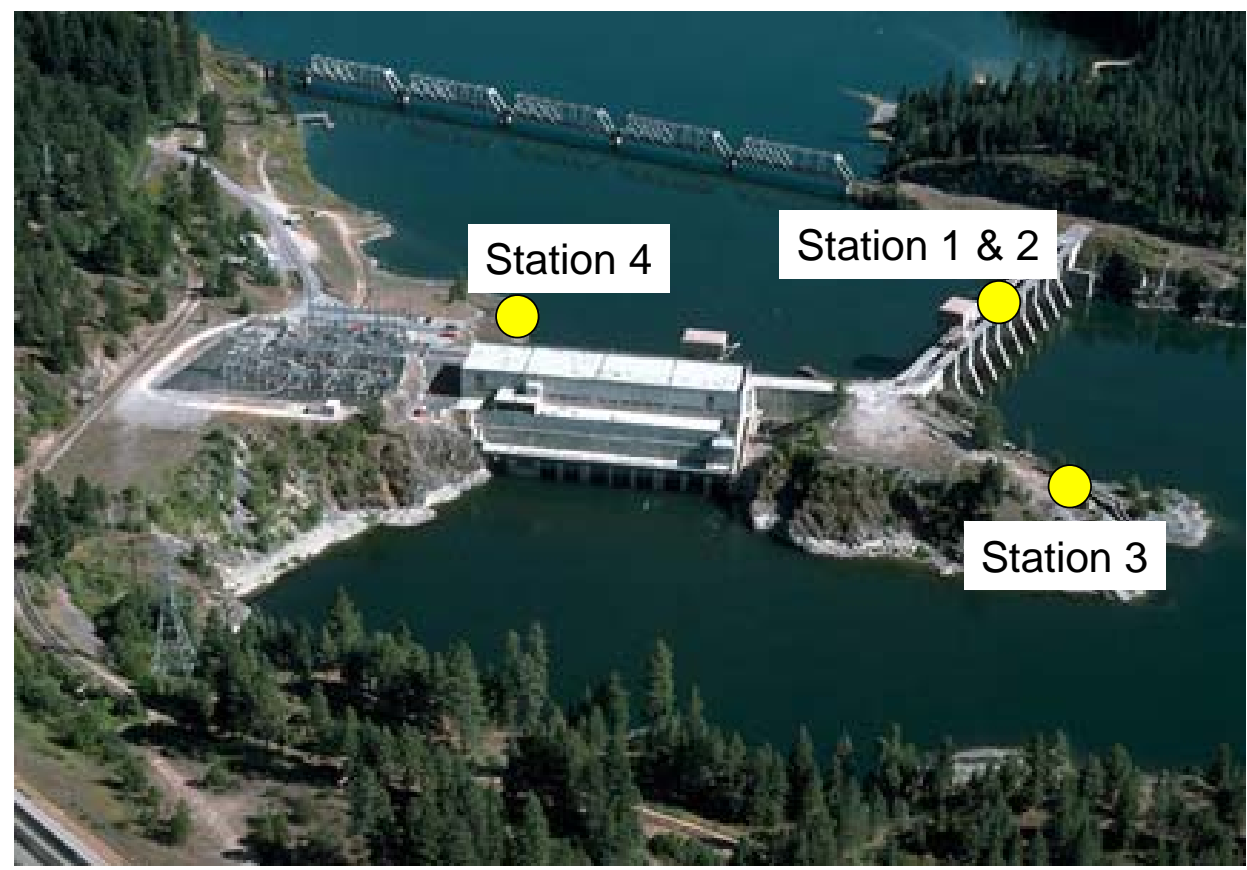

Figure 2. Locations of radio receiving monitoring stations at Albeni Falls Dam in 2008 
Receivers were downloaded approximately once every two weeks during operation in 2008 by PNNL or EWU staff (Table 2). A standard operating procedure was used in 2008 to ensure data quality control during each download. This procedure involved a basic check of monitoring station performance and guidelines for saving and maintaining data. Staff ensured that interference signals were minimal (to allow for detection of fish transmitters), the beacon transmitter was detected hourly, the solar panel was charging the internal batteries, and the station was inspected for damage. Data were saved to a laptop computer and backed up to a removable thumb drive. Data collected by EWU were then sent to PNNL within a few working days. All receivers except those for the Tailrace, Forebay, and Logchute were removed in fall 2008. The three Albeni Falls Dam receivers will continue to collect data during winter 2008-2009 for a study funded by the U.S. Army Corps of Engineers (USACE) to track bull trout movements downstream of Albeni Falls Dam and concurrently will collect data on bull trout tagged for this study.

Table 2. Operation dates of radio receiving stations in 2008. End dates marked as N/A indicate that receivers were not removed in fall 2008 and will continue to record data during winter 20082009.

\begin{tabular}{lccc}
\hline Receiver Name & Site \# & Start Date & End Date \\
\hline Tailrace & 1 & 25 February 2008 & N/A \\
Forebay & 2 & 25 February 2008 & N/A \\
Logchute & 3 & 26 February 2008 & N/A \\
Cement Pad & 4 & 25 February 2008 & 26 November 2008 \\
Mudhole & 5 & 26 February 2008 & 25 October 2008 \\
North Dover & 6 & 11 March 2008 & 26 November 2008 \\
South Dover & 7 & 26 February 2008 & 26 November 2008 \\
Gold & 8 & 12 June 2008 & 25 October 2008 \\
Granite & 9 & 12 June 2008 & 25 October 2008 \\
Lightning & 10 & 27 February 2008 & 26 November 2008 \\
Trestle & 11 & 11 March 2008 & 26 November 2008 \\
\hline
\end{tabular}

PNNL and EWU staff made miscellaneous repairs to radio receiving stations during 2008. A nineelement Yagi was installed to replace the six-element Yagi at the Logchute station (site 3) to decrease the reception range of the station and improve the capability to detect fish entering the powerhouse tailrace. In addition, a solar panel charger controller was replaced at the North Dover (site 6) station. Further, an additional deep-cycle battery and solar panel were added to the Trestle Creek (site 11) station to increase battery life.

\section{Work Element G: 119 - Manage and Administer Projects - Manage project}

Labor to accomplish electrofishing, mobile tracking, downloading of monitoring stations, and assembling data were coordinated in 2009 among staff from EWU, the Kalispel Tribe, and PNNL. A budget and statement of work for 2009 and the current property inventory are being assembled and will be submitted to BPA in January 2009. 


\section{Work Element H: 70 - Install Fish Monitoring Equipment - Annual overhaul and recalibration of ground receiver stations}

Reception range of all monitoring stations was tested after installation of receivers in 2008 (Figures 3 through 6). The four stations at Albeni Falls Dam and the Mudhole station were tested in mid-March 2008. The North and South Dover stations on the Pend Oreille River were tested in early April 2008. The stations on Lake Pend Oreille tributaries were tested on the same dates as receiver reinstallations in Table 1. Transects located about $100 \mathrm{~m}$ apart, parallel to the concrete of the dam spillway and extending the width of the river, were used to test the tailrace and forebay receivers on the dam spillway. A linear transect extending from the downstream end of the dam logchute to the opposing bank of the powerhouse tailrace was used to test the powerhouse tailrace monitoring station. A linear transect extending across the forebay, parallel to the powerhouse, was used to test the powerhouse forebay monitoring station. Reception range of the Dover receiving stations was tested at five equally spaced points along a linear transect that extended from the North station to the South station (Figure 5). At about $50 \mathrm{~m}$ along each transect at Albeni Falls Dam and at the five points of the Dover transect, a transmitter was lowered to depths of $1,3,5,7$, and $10 \mathrm{~m}$ (or up to the maximum depth) and the signal strength of the transmitter decoded by the receiver was recorded. Range testing of receivers at the mouth of the Priest River and the Pend Oreille Lake tributaries was used to calibrate receivers so that transmitters could be decoded across the width of the tributary at all depths and upstream and downstream movements could be differentiated.

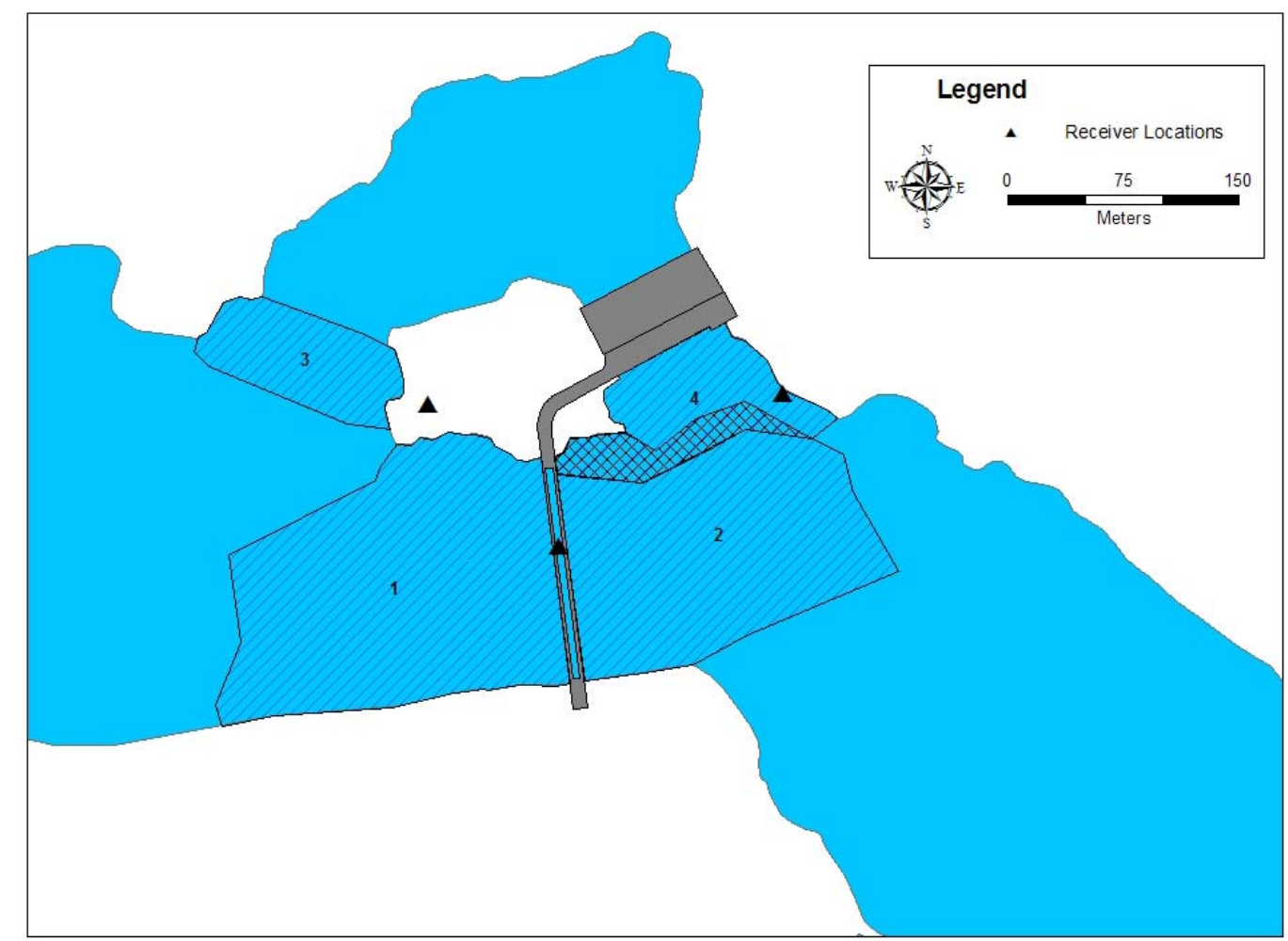

Figure 3. Reception range of receivers at Albeni Falls Dam at 1-m depth in spring 2008. The simplehatched polygons represent areas in which radio receivers decoded a CART transmitter with power greater than 100 . Numbered polygons correspond to receivers monitoring the spillway tailrace (1), spillway forebay (2), powerhouse tailrace (3, Logchute receiver), and powerhouse forebay (4, Cement Pad receiver). The cross-hatched polygon denotes range overlap between receivers 2 and 4. 


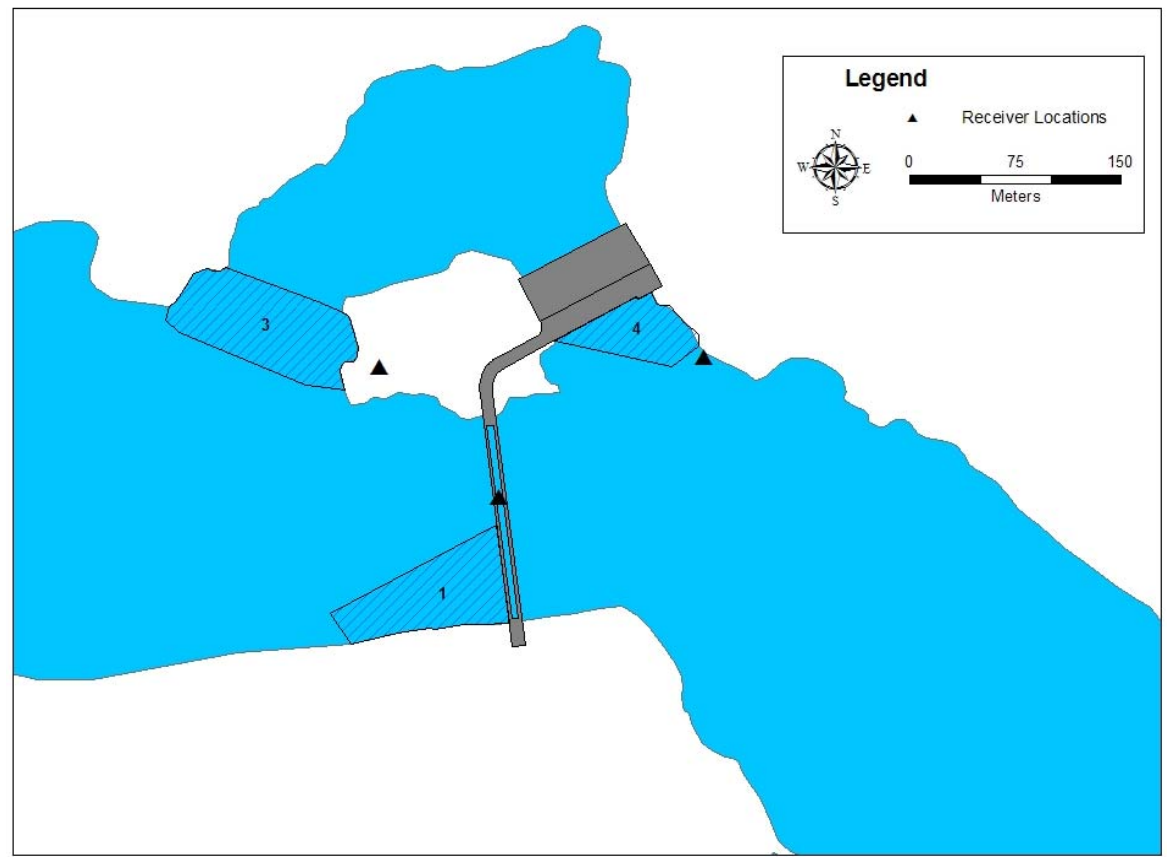

Figure 4. Reception range of receivers at Albeni Falls Dam at 5-m depth in spring 2008. The simplehatched polygons represent areas in which the respective radio receivers decoded a fish transmitter with power greater than 100 . Numbered polygons correspond to receivers monitoring the spillway tailrace (1), powerhouse tailrace (3, Logchute receiver), and powerhouse forebay (4, Cement Pad receiver).

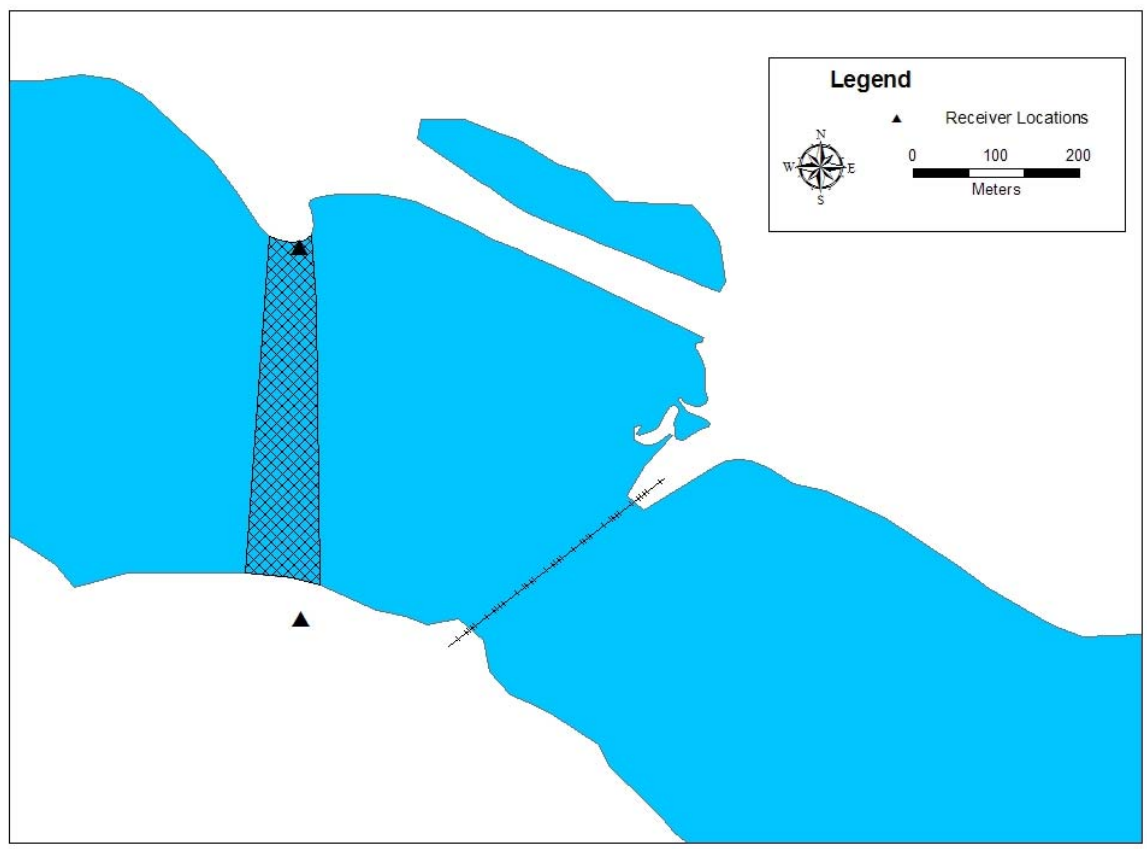

Figure 5. Reception range of the North Dover and South Dover receivers on the Pend Oreille River at 1 -m depth in spring 2008. The cross-hatched polygon represents the area in which the radio receivers decoded a fish transmitter with a power greater than 100 . The railroad bridge near Dover, Idaho, is denoted by the hatched line extending from the north to south bank of the river, where receivers were located in 2007. 


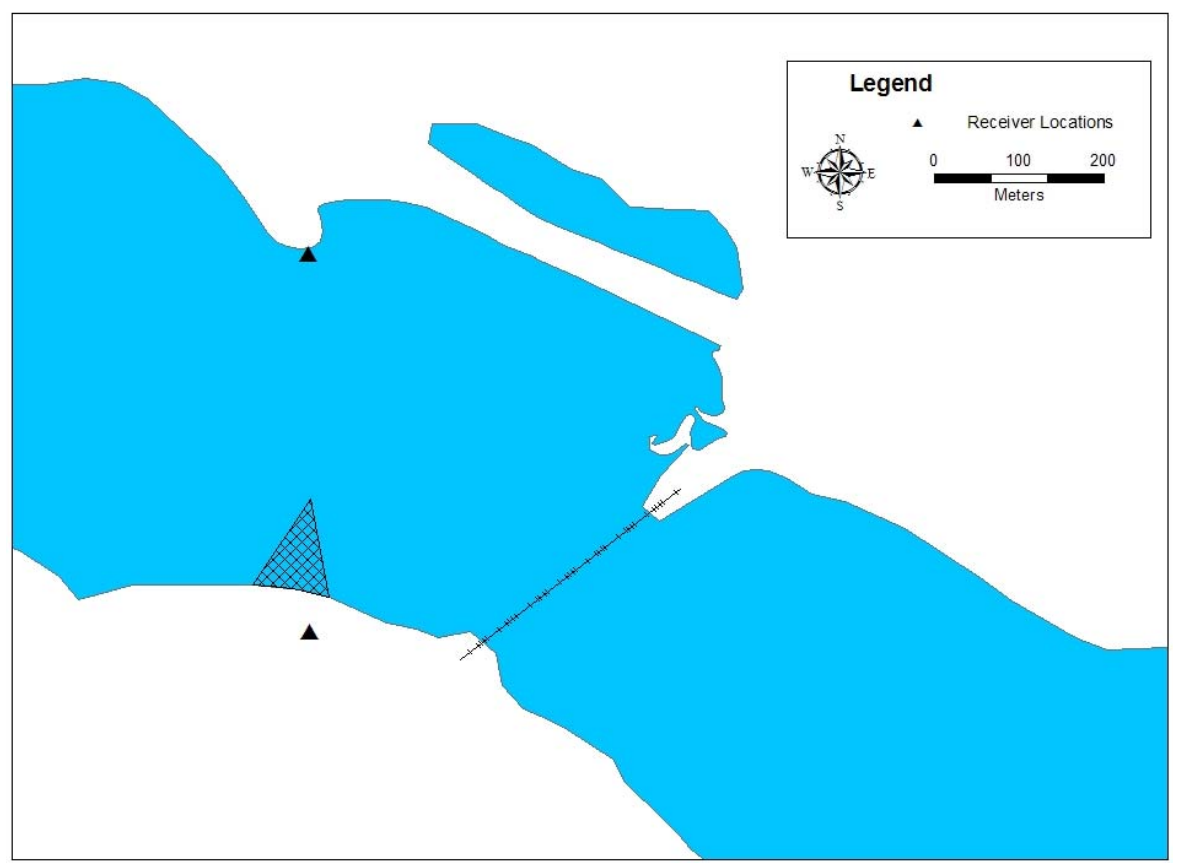

Figure 6. Reception range of the North Dover and South Dover receivers on the Pend Oreille River at 5-m depth in spring 2008. The cross-hatched polygon represents the area in which the South Dover radio receiver decoded a fish transmitter with a power greater than 100 . The railroad bridge near Dover, Idaho, is denoted by the hatched line extending from the north to south bank of the river, where receivers were located in 2007.

Reception range of the tailrace and logchute receivers was retested in September 2008 after hardware changes to the logchute receiver and programming changes to the tailrace receiver (Figure 7). These changes were necessary to simultaneously meet the objectives for the current study and the USACEfunded study mentioned in Work Element F. To test receivers, multiple test transmitters were dragged throughout the tailrace at varying depths while receivers simultaneously decoded transmitters. Transmitter location data were then paired with receiver detection data to quantify the reception range of all receivers interrogating the Albeni Falls Dam tailrace, including the additional receivers installed for the USACE study (Figure 7).

The greater detection range of the Tailrace and Logchute receivers in September 2008 than spring 2008 likely is due to differences in testing methodology. Detection range was tested in the spring at specific points in the tailrace to ensure that transmitters would be detected downstream of the spillway, but points did not encompass the entire range of the receivers. In September 2008, the testing methodology was designed to find the ultimate range of each receiver, and, subsequently, the detection ranges differed. Additionally, transmitters were in the water for a much longer period during the September testing and thus provide a more accurate depiction of receiver range. 


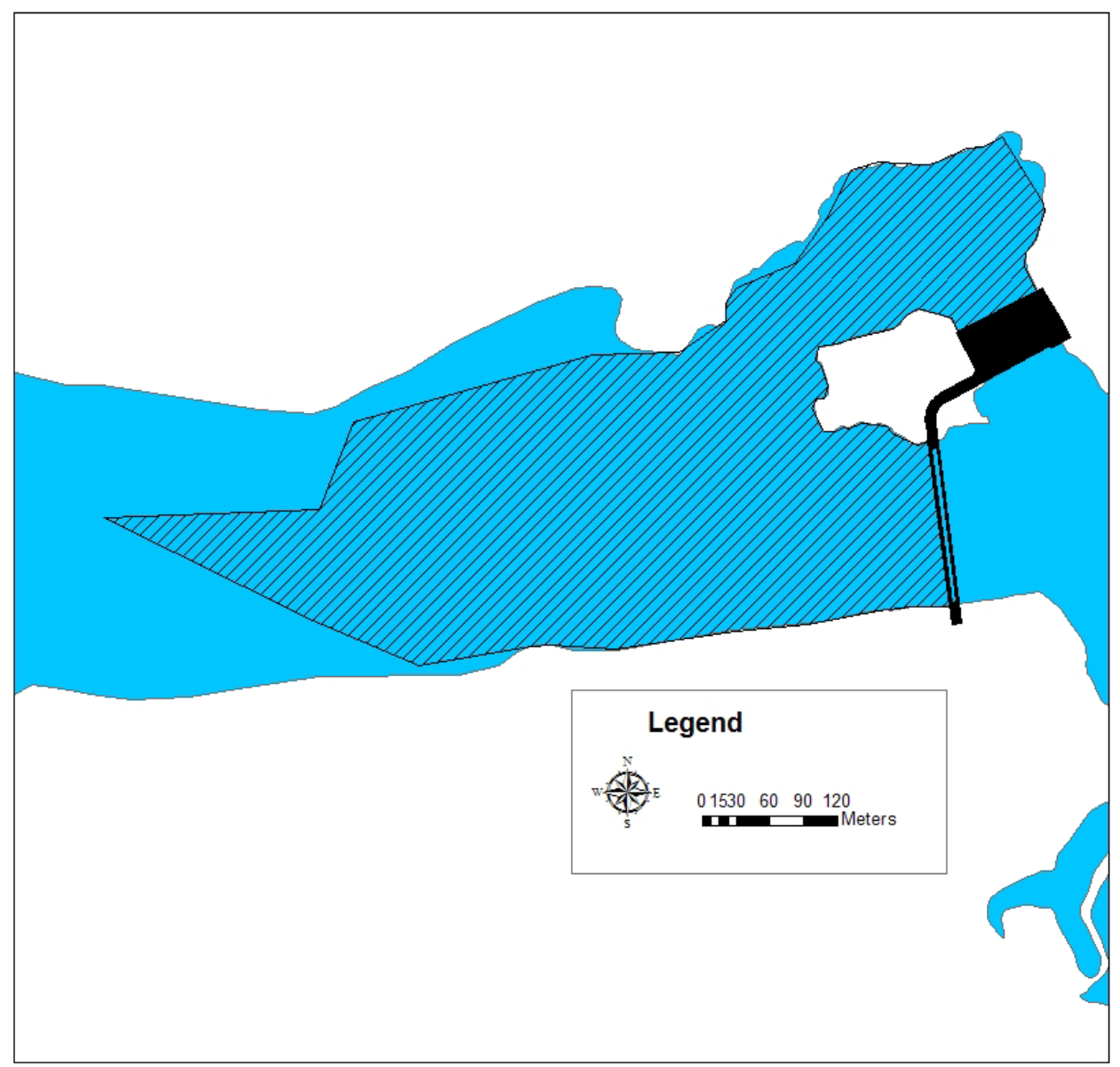

Figure 7. Reception range downstream of Albeni Falls Dam beginning 18 September 2008. The simplehatched polygons represent areas in which the radio receivers decoded a radio transmitter with power greater than 100 . The polygon represents the detection range of all receivers combined, including receivers installed for the concurrent USACE study.

\section{Work Element I: 185 - Produce Pisces Status Report - Periodic status reports for BPA}

PNNL submitted quarterly status reports to BPA through the Pisces reporting system.

\section{Work Element J: Analyze/Interpret Data - Data reduction and analysis}

Data files downloaded from radio receiving stations were checked for quality and loaded into a database for summarization and analysis. Detection histories of each bull trout were then queried from the database containing radio receiving station data, supplemented with mobile tracking data, and are reported below. Only detection data collected from the time of transmitter implantation through 15 November 2008 are included in this progress report. Fish detection data from 15 November 2008 through 15 November 2009 will be provided in the 2009 progress report. 


\section{Detection histories}

Fish 126 - Fish 126 was caught downstream of Albeni Falls Dam, implanted with a CART transmitter, and released at the Priest River boat launch on 19 May 2008. Genetic analyses predicted that this fish was about 68 times more likely to have originated from Grouse Creek (most likely) than Trestle Creek (second most likely). The North and South Dover receiving stations detected this fish on 11 and 12 June 2008, and it was not detected thereafter.

Fish 128 - Fish 128 was caught downstream of Albeni Falls Dam, implanted with a CART transmitter, and released at the Priest River boat launch on 19 May 2008. Genetic analyses predicted that this fish was $2.577 \times 10^{7}$ times more likely to have originated from Grouse Creek (most likely) than Rattle Creek (second most likely). It was detected at the South Dover station on 28 May 2008 at 0600 hours. On 11 October 2008, it was detected during aerial tracking over Grouse Creek (N 48 27.829 W 116 16.352$)$. On 22 October 2008, tag 128 was found in Grouse Creek and recovered (N 48 $27.924 \mathrm{~W}$ $116^{\circ} 16.180$ ); no fish carcass was seen in the area. No predator teeth marks were seen on the tag, suggesting that the transmitter may have exited the fish during spawning.

Fish 172 - Fish 172 was caught downstream of Albeni Falls Dam, implanted with a NANO transmitter, and released at the Priest River boat launch on 11 June 2008. Genetic analyses predicted that this fish was about 5 times more likely to have originated from Lightning Creek (most likely) than Gold Creek (second most likely). It was detected at the North Dover station on 18 June 2008 at 0800 hours and was not detected thereafter.

Fish 108 - Fish 108 was caught downstream of Albeni Falls Dam, implanted with a CART transmitter, and released at the Priest River boat launch on 18 June 2008. Genetic analyses predicted that this fish was about 15 times more likely to have originated from Rattle Creek (most likely) than Morris Creek (second most likely), which are both tributaries of Lightning Creek. It was first detected at the Mudhole receiver (mouth of Priest River) on 18 June at 2000 hours and again on 4 July at 2300 hours. There are no detection data to explain where this fish was between the subsequent detections at the Mudhole receiver; however, based on detection signal strengths, it is not likely that the fish passed the receiving station and went upstream into the Priest River. Fish 108 was then detected passing the Dover receiving stations on 5 July 2008 at 2000 hours. The final detections of this fish were recorded in the Clark Fork River near the Cabinet Gorge Fish Hatchery on 22 (by aircraft) and 26 (by boat) September 2008 by AVISTA staff. This fish was detected several times also on 25 September at Cabinet Gorge Dam by AVISTA staff. Vehicle mobile tracking of the Clark Fork River on 8 October by PNNL staff did not detect fish 108, suggesting that it left the Clark Fork River or was in deep water and out of the detection range. This fish was not detected entering Lightning Creek.

We suspect that fish 108 may not have moved to its genetically-assigned spawning tributary because the entire width of Lightning Creek was flowing subsurface a few hundred meters upstream of the Lightning Creek monitoring station in September 2008. If this fish had moved upstream into Lightning Creek far enough to realize the river was subsurface, it presumably would have been detected at the Lightning Creek monitoring station. However, at the time Lightning Creek was subsurface, the U.S. Army Corp of Engineers had re-routed the thalweg of the creek to the far side of the river channel, approximately $70 \mathrm{~m}$ from our receiving station. This alternate channel was not tested during range tests of the Lightning Creek station and consequently, it is possible that fish 108 moved through this section of Lightning Creek undetected. 


\section{Work Element K: Produce (Annual) Progress Report - Submit annual report for the period May 2008 to April 2009}

The report described herein satisfies this work element. A comprehensive final report will be submitted in the final year of the study.

\section{Equipment Purchased}

Equipment purchased by PNNL in 2008 included one Knaack equipment box, one Garmin GPS unit, six 12-V deep-cycle batteries, and consumable supplies for maintenance of radio receiving stations. Additional items were purchased in the 2007 contract year but were not included in the 2007 report because they were purchased between finalization of the report and the beginning of the 2008 contract year. These items include two Knaack equipment boxes, one safety harness, and one 20-ft extension ladder for installation of radio antennae in trees, two deep-cycle batteries, and five beacon transmitters. In addition, six radio receivers were sent in for repair and tuning to Lotek Wireless, Inc.

\section{Plans for 2009}

One radio receiving station will be installed in 2009 to detect fish entering the Pack River because two bull trout tagged in 2008 were designated as probable descendants from the Grouse Creek spawning population. The addition of a receiving station at the Pack River likely will cover all potential spawning tributaries of bull trout between Albeni Falls Dam and Cabinet Gorge Dam. However, we will continue to use genetic data in 2009 and will relocate stations if necessary to determine migration paths of tagged bull trout.

Acoustic mobile tracking efforts need to be increased in 2009 to identify lake-staging areas of bull trout in Pend Oreille Lake. Acoustic tracking efforts in 2008 were unsuccessful due to poor reception range of the acoustic hydrophone. Currently we are working with the manufacturer to improve detection range of the hydrophone and will test it sufficiently before surveys in 2009. We also may continue to coordinate with Idaho Fish and Game staff who assisted us with acoustic tracking surveys in 2008.

Electrofishing effort will continue in spring 2009 to attempt to capture additional bull trout and transport them around Albeni Falls Dam. Staff from PNNL assisted with two surveys in 2008. However, planning of electrofishing trips by EWU and the Kalispel Tribe is often done at the last minute, so it is difficult for staff at PNNL to participate in these trips. Consequently, PNNL will be responsible for less electrofishing trips in 2009 but will be available if EWU or Kalispel Tribe help is not available.

\section{References}

Bellgraph, Brian J., and Katherine A. Deters. 2007. Temporary restoration of bull trout passage at Albeni Falls Dam - 2007 Progress Report. Document ID P105339, Bonneville Power Administration, Portland, Oregon. 
Paluch, Mark C., Alan T. Scholz, Holly J. McLellan, and Jason Olson. 2009. Temporary restoration of bull trout passage at Albeni Falls Dam - 2008 Progress Report. Bonneville Power Administration Contract \#2007-246-00. Bonneville Power Administration, Portland, Oregon. 